Șerban Al. O., Obadă B. , Botnaru V., Valcu Al.

\title{
Etiopathogenical criteria in the early diagnosis of Compartmental Syndrome [CS] of the shank
}

Clinic of Orthopedics and Traumatology, Emergency County Hospital Constanța, Romania

\begin{abstract}
Through the evaluation of some etiopathogenic risk factors one can anticipate the evaluation of some fractures towards Compartmental Syndrome (CS) and then their diagnosis in early stage, when the symptomatology is still unconvincing and the treatment reduces the risk of ischemia lesions. Based both on some prospective observations, using a group of shank fractures, and also on the clinical facts of constituted CS, there were made correlations, statistically reported in the case of some etiopathogenic risk factors represented by the fracture localization and its characteristics, traumatic mechanisms, soft tissue quality and polytraumatism, having an objective common denominator, the compartmental pressure level measured directly. The authors propose an etiopathogenic risk score of $\mathrm{CS}$ for the fractures reaching the pressure level of $20-30 \mathrm{mmHg}$, recommending the pressional and clinical monitoring for a score of minimum 10 points. These fractures have a certain risk of $\mathrm{CS}$.
\end{abstract}

Keywords: Compartmental syndrome, shank, criteria, pressure level

\section{Obada Bogdan}

Clinic of Orthopedics and Traumatology

Emergency County Hospital Constanța, Romania

bogdanobada@yahoo.com

\section{Introduction}

The shank has ideal anatomical conditions to develop a pressional conflict in his compartments, being the region with the most frequent localization of CS. The compartmental spaces, with physiological value in normal conditions, become hurtful for the anatomical structures contented, due to a characteristic microcirculatory unbalance characteristic for CS $[1,2]$.

The clinical and experimental research sustains the complex character of the CS physiopathology which is the same with the microcirculatory physiopathology in the phase of the decompensation of the changes between vessels and tissues. The complex implication of the enzymatic, metabolism and biochemical factors which cannot be measured as quality and quantity in emergency conditions, make to be difficult to find the risk or the precocious diagnosis using classical labor methods.

The clinical experience demonstrated that CS cannot be explained as a complication, logical to traumatism, although it appears secondary to a trauma, but it is known, there is also a nontraumatic etiology. The traumatic etiopathogeny can be a risk factor, but it has not an absolute value, direct as cause and effect to develop a CS [3]. 
After a start of CS with an incomplete clinical presentation or with unconvincing symptomatology, the early diagnosis can be difficult to establish, which delay the surgical treatment, as result progressive ischemical lesions [4].

The paper propose to evaluate some etiopathogenic criteria under pressional report, phisiopathological and clinical and to establish a risk score useful to have a precocious diagnosis through continuous clinical and pressional monitorisation.

\section{Material and Methods}

1. Prospective pressional study upon 268 shank fractures (2012-2014). 2014).

2. Clinical study upon 64 cases of CS (2008-

3. Direct compartmental pressional measurement - Whiteside technique [5], Stryker technique (Figure $1 \& 2$ ).

4. The evaluation of some etiopathogenic risk factors upon pressional periods:

- fracture localization;

- traumatic mechanism;

- fracture characteristics;

- soft tissue quality;

- politraumatic associations;

- pressional dynamics.

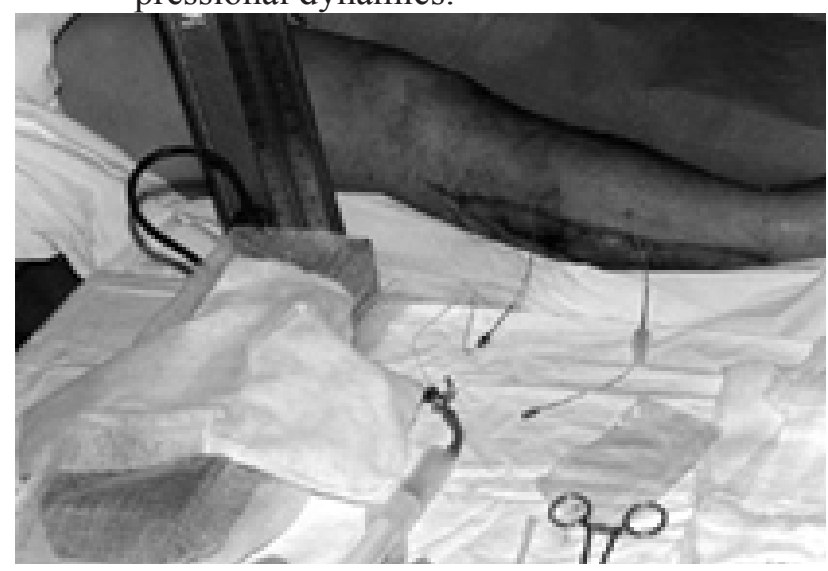

Figure1 - Whiteside technique

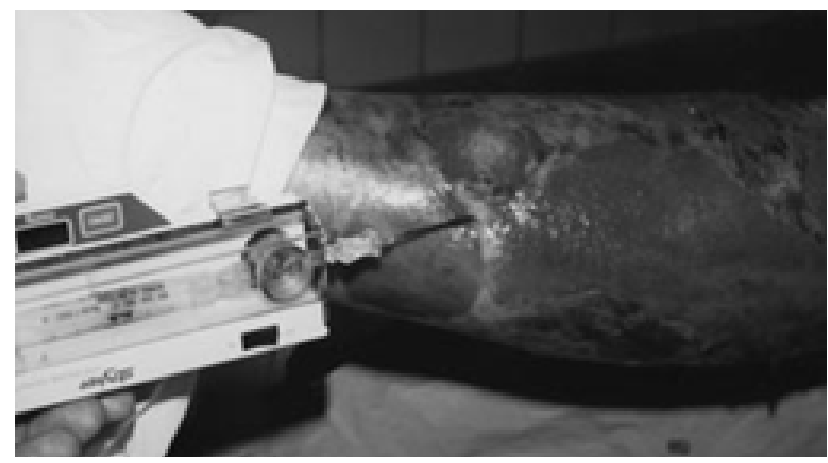

Figure 2 - Stryker technique

\section{Results}

In relation with the period of time from the accident to the first measurement, taking as working place the antero-external compartment, the structure of casuistry in relation with the localization of fracture was the following (Table I):

Table I - Fracture prospective group 2012-2014

Frequency of fractures in relation with the period of time when the initial manometry was made

\begin{tabular}{|c|c|c|c|c|c|}
\hline \multirow[b]{2}{*}{ Localization } & \multirow[b]{2}{*}{ Total } & \multicolumn{4}{|c|}{ Time accident - first manometry (hours) } \\
\hline & & $1-6$ & $6-12$ & $\begin{array}{l}12-24 \\
\text { hours }\end{array}$ & $\begin{array}{l}24-72 \\
\text { hours }\end{array}$ \\
\hline \multicolumn{6}{|c|}{ 1. Epiphyseal fractures } \\
\hline $\begin{array}{l}\text { Proximal tibia, } \\
\text { peroneus }\end{array}$ & 48 & 27 & 14 & 5 & 2 \\
\hline \multicolumn{6}{|c|}{ 2. Diaphyseal fractures } \\
\hline $1 / 3$ proximal & 63 & 29 & 23 & 11 & \\
\hline $1 / 3$ medium & 98 & 34 & 29 & 17 & 18 \\
\hline $\begin{array}{l}\text { 1/3medium- } \\
1 / 3 \text { distal }\end{array}$ & 41 & 14 & 18 & 5 & 4 \\
\hline 1/3distal & 18 & 2 & 8 & 5 & 3 \\
\hline TOTAL & 268 & 79 & 78 & 38 & 25 \\
\hline
\end{tabular}

Traumatic mechanism evaluated anamnesthical, clinical, radiological and anatomopathological is considered to be direct (high energy) in 155 cases and indirect (low energy) 113 cases. This systematization is referred to the type of predominant mechanism, in reality being the 
Table II - Pressure interval $15-20 \mathrm{mmHg}$

Basic characteristics of the fractures that evolved to CS

\begin{tabular}{||l|l|l|l|l|l|l|l||}
\hline \hline No & Localization & $\begin{array}{c}\text { Time to } \\
\text { first } \\
\text { manom. }\end{array}$ & \multicolumn{1}{|c||}{$\begin{array}{c}\text { Time to } \\
\text { diagnosis }\end{array}$} & Mechanism & Fracture type & $\begin{array}{c}\text { Soft tissue } \\
\text { quality }\end{array}$ & Politrauma \\
\hline & Diaphysis & & \multicolumn{5}{||}{} \\
\hline 1. & First $1 / 3$ & 3 hours & 27 hours & Direct & Comminuted & Open III A & Yes \\
\hline 2. & First $1 / 3$ & 6 hours & 30 hours & Direct & Comminuted & Open III A & No \\
\hline 3. & First $1 / 3$ & 2 hours & 26 hours & Indirect & Comminuted & Closed & Yes \\
\hline 4. & Second $1 / 3$ & 2 hours & 26 hours & Direct & Comminuted & Closed & No \\
\hline 5. & Second $1 / 3$ & 1 hour & 49 hours & Indirect & Comminuted & Closed & No \\
\hline 6. & Third $1 / 3$ & 2 hours & 50 hours & Direct & Simple & Closed & No \\
\hline \hline
\end{tabular}

association of the both mechanisms.

Characteristics of the fracture site:

- simple fractures - 140 cases

- comminuted fractures - 128 cases

Soft tissue quality:

- closed fractures - 162 cases IIIA,B)

- open fractures - 110 cases (Gustilo I, II,

It was made an analysis of the etiopathogenic factors with risk value for the pressional criterion (first manometry) and the time periods from the accident.

1. Pressure interval $15-20 \mathrm{mmHg}-41.4 \%$ (111 cases) of which $40.5 \%$ (45) reached this level in the first 6 hours from the accident, $39.6 \%$ (44) between 6-12 hours, and the rest of the cases over 12-24 hours and even 72 hours. From this interval, 5.4\% (6) turned to CS presenting the following base characteristics (Table II):

2. Pressure interval $21-25 \mathrm{mmHg}-38.4 \%$ (103 cases) of which $45.6 \%$ (47) reached this level in the first 6 hours. Turned to CS $4.8 \%$ (5) presenting the following base characteristics (Table III):

3. Pressure interval $26-30 \mathrm{mmHg}-11.9 \%$ (32 cases) of which $28.1 \%$ (9) reached this level in the first 6 hours. Turned to CS $15.6 \%$ (5) presenting the following base characteristics (Table IV):

4. Pressure interval $31-40 \mathrm{mmHg}-5.2 \%$ (14 cases) of which $14.2 \%$ (2) reached this level in the first 6 hours and turned to CS 7.1\% (1) presenting the following base characteristics (Table V):

5. Pressure interval $41-100 \mathrm{mmHg}-2.9 \%(8$ cases) was diagnosed with CS (Table VI):

Table III - Pressure interval $21-25 \mathrm{mmHg}$

Basic characteristics of the fractures that evolved to CS

\begin{tabular}{||l|l|l|l|l|l|l|l|l||}
\hline \hline No & \multicolumn{1}{|c|}{ Localization } & $\begin{array}{c}\text { Time to first } \\
\text { manom. }\end{array}$ & \multicolumn{1}{|c|}{$\begin{array}{c}\text { Time to } \\
\text { diagnosis }\end{array}$} & Mechanism & Fracture type & $\begin{array}{c}\text { Soft tissue } \\
\text { quality }\end{array}$ & Politrauma \\
\hline & Epiphysis & \multicolumn{5}{|l||}{} \\
\hline 1. & Schatzker V type & 1 hour & 13 hours & Direct & Simple & Closed & Yes \\
\hline 2. & Schatzker IV type & 1 hour & 5 hours & Indirect & Simple & Closed & Yes \\
\hline & Diaphysis & \multicolumn{5}{|l||}{} \\
\hline 3. & First $1 / 3$ & 2 hours & 50 hours & Direct & Comminuted & Open III A & Yes \\
\hline 4. & First $1 / 3$ & 3 hours & 50 hours & Indirect & Simple & Closed & No \\
\hline 5. & Second $1 / 3$ & 2 hours & 50 hours & Indirect & Simple & Closed & No \\
\hline \hline
\end{tabular}


Table IV - Pressure interval 26 - $30 \mathrm{mmHg}$

Basic characteristics of the fractures that evolved to CS

\begin{tabular}{||l|l|l|l|l|l|l|l||}
\hline \hline No & \multicolumn{1}{|c|}{ Localization } & \multicolumn{1}{|c|}{$\begin{array}{c}\text { Time to } \\
\text { first } \\
\text { manom. }\end{array}$} & \multicolumn{1}{|c|}{$\begin{array}{c}\text { Time to } \\
\text { diagnosis }\end{array}$} & Mechanism & Fracture type & $\begin{array}{c}\text { Soft } \\
\text { tissue } \\
\text { quality }\end{array}$ & Politrauma \\
\hline & Epiphysis & \multicolumn{5}{|l||}{} \\
\hline 1. & Schatzker V type & 2 hours & 26 hours & Direct & \multicolumn{1}{|l||}{ Comminuted } & Closed & Yes \\
\hline & Diaphysis & \multicolumn{7}{|l||}{} \\
\hline 2. & Second $1 / 3$ & 7 hours & 15 hours & Direct & Simple & Open I & No \\
\hline 3. & Second $1 / 3$ & 7 hours & 9 hours & Direct & Simple & Closed & No \\
\hline 4. & Second $1 / 3$ & 3 hours & 11 hours & Direct & Comminuted & Open II & Yes \\
\hline 5. & Second $1 / 3$ & 3 hours & 11 hours & Direct & Simple & Closed & Yes \\
\hline \hline
\end{tabular}

Table V-Pressure interval 31 - $40 \mathrm{mmHg}$

Basic characteristics of the fractures that evolved to $C S$

\begin{tabular}{||l|l|l|l|l|l|l|l||}
\hline \hline No & Localization & $\begin{array}{c}\text { Time to } \\
\text { first } \\
\text { manom. }\end{array}$ & $\begin{array}{c}\text { Time to } \\
\text { diagnosis }\end{array}$ & Mechanism & Fracture type & $\begin{array}{c}\text { Soft } \\
\text { tissue } \\
\text { quality }\end{array}$ & Politrauma \\
\hline & Diaphysis & & \multicolumn{1}{|l||}{} \\
\hline 1. & First $1 / 3$ & 11 hours & 11 hours & Direct & Comminuted & Open II & No \\
\hline \hline
\end{tabular}

Table VI - Pressure interval 41 - $100 \mathrm{mmHg}$

Basic characteristics of the fractures that evolved to $C S$

\begin{tabular}{||l|l|l|l|l|l||}
\hline \hline No & Localization & \multicolumn{1}{|c|}{$\begin{array}{l}\text { Time to } \\
\text { diagnosis }\end{array}$} & Fracture type & $\begin{array}{l}\text { Soft tissue } \\
\text { quality }\end{array}$ & Politrauma \\
\hline & Epiphysis & \multicolumn{4}{|l||}{} \\
\hline 1. & $\begin{array}{l}\text { Schatzker } \\
\text { IV type }\end{array}$ & 3 hours & Comminuted & Closed & No \\
\hline 2. & $\begin{array}{l}\text { Schatzker V } \\
\text { type }\end{array}$ & 6 hours & Simple & Closed & No \\
\hline 3. & $\begin{array}{l}\text { Schatzker V } \\
\text { type }\end{array}$ & 6 hours & Simple & Closed & Yes \\
\hline 4. & $\begin{array}{l}\text { Schatzker V } \\
\text { type }\end{array}$ & 7 hours & Comminuted & Closed & Yes \\
\hline 5. & $\begin{array}{l}\text { Schatzker } \\
\text { IV type }\end{array}$ & 3 hours & Simple & Open II & No \\
\hline & Diaphysis & & & & No \\
\hline 6. & First $1 / 3$ & 24 hours & Comminuted & Open II & No \\
\hline 7. & Second $1 / 3$ & 10 hours & Simple & Open I & No \\
\hline 8. & Distal $1 / 3$ & 18 hours & Simple & Open II & No \\
\hline \hline
\end{tabular}

The risk probability of $\mathrm{CS}$, in relation with the pressure interval, localization of fracture and the time period from the accident are presented in tables VII to IX:
Table VII - CS risk in relation with pressure interval and fracture localization

\begin{tabular}{|c|c|c|c|c|c|c|}
\hline \multirow{2}{*}{$\begin{array}{l}\text { Pressure } \\
\text { interval }\end{array}$} & \multirow{2}{*}{$\begin{array}{c}\text { Casuistry } \\
\text { CS }\end{array}$} & \multicolumn{5}{|c|}{ Fracture localization } \\
\hline & & Epiphysis & $\begin{array}{c}\text { Entire } \\
\text { diaphysis }\end{array}$ & First $1 / 3$ & $\begin{array}{c}\text { Second } \\
1 / 3\end{array}$ & $\begin{array}{c}\text { Distal } \\
1 / 3 \\
\end{array}$ \\
\hline \multirow{2}{*}{$\begin{array}{l}15-20 \\
\mathrm{mmHg}\end{array}$} & $\begin{array}{c}111 \\
(41.4 \%)\end{array}$ & $\begin{array}{c}1 \\
(0.4 \%) \\
\end{array}$ & $\begin{array}{c}23 \\
(8.6 \%) \\
\end{array}$ & $\begin{array}{c}38 \\
(14.2 \%) \\
\end{array}$ & $\begin{array}{c}36 \\
(9.7 \%) \\
\end{array}$ & $\begin{array}{c}13 \\
(4.8 \%) \\
\end{array}$ \\
\hline & $\begin{array}{c}6 \\
(5.4 \%) \\
\end{array}$ & & $\begin{array}{c}3 \\
(13 \%)\end{array}$ & $\begin{array}{c}1 \\
(2.6 \%)\end{array}$ & $\begin{array}{c}2 \\
(5.5 \%) \\
\end{array}$ & \\
\hline \multirow{2}{*}{$\begin{array}{l}21-25 \\
\mathrm{mmHg}\end{array}$} & $\begin{array}{c}103 \\
(38.4 \%) \\
\end{array}$ & $\begin{array}{c}24 \\
(9.0 \%)\end{array}$ & $\begin{array}{c}23 \\
(8.6 \%) \\
\end{array}$ & $\begin{array}{c}48 \\
(18 \%)\end{array}$ & $\begin{array}{c}3 \\
(1.12 \%)\end{array}$ & $\begin{array}{c}5 \\
(1.9 \%)\end{array}$ \\
\hline & $\begin{array}{c}5 \\
(4.8 \%) \\
\end{array}$ & $\begin{array}{c}2 \\
(8.3 \%) \\
\end{array}$ & $\begin{array}{c}2 \\
(8.6 \%) \\
\end{array}$ & & $\begin{array}{c}1 \\
(33 \%)\end{array}$ & \\
\hline \multirow{2}{*}{$\begin{array}{l}26-30 \\
\mathrm{mmHg}\end{array}$} & $\begin{array}{c}32 \\
(11.9 \%)\end{array}$ & $\begin{array}{c}10 \\
(3.7 \%)\end{array}$ & $\begin{array}{c}14 \\
(15.22 \%)\end{array}$ & $\begin{array}{c}8 \\
(3 \%)\end{array}$ & & \\
\hline & $\begin{array}{c}5 \\
(15.6 \%) \\
\end{array}$ & $\begin{array}{c}1 \\
(10 \%)\end{array}$ & & $\begin{array}{c}4 \\
(50 \%) \\
\end{array}$ & & \\
\hline \multirow{2}{*}{$\begin{array}{l}31-40 \\
\mathrm{mmHg}\end{array}$} & $\begin{array}{c}14 \\
(5.2 \%) \\
\end{array}$ & $\begin{array}{c}8 \\
(57 \%) \\
\end{array}$ & $\begin{array}{c}2 \\
(14.2 \%) \\
\end{array}$ & $\begin{array}{c}3 \\
(21 \%) \\
\end{array}$ & $\begin{array}{c}1 \\
(7.1 \%)\end{array}$ & \\
\hline & $\begin{array}{c}1 \\
(7.1 \%) \\
\end{array}$ & $\begin{array}{c}1 \\
(12.5 \%) \\
\end{array}$ & & & & \\
\hline $\begin{array}{l}44-100 \\
\mathrm{mmHg}\end{array}$ & 8 & 5 & 1 & 1 & 1 & \\
\hline Total & $\mathrm{CS}=25$ & & & & & \\
\hline
\end{tabular}


Table VIII - Prospective group - Probability of CS risk in relation with fracture localization and interval between accident and first manometry (at admittance)

\begin{tabular}{|c|c|c|c|c|}
\hline Fracture localization & No & $\mathrm{CS}$ & $\% \mathrm{CS}$ & $\begin{array}{c}\text { Interval from } \\
\text { accident }\end{array}$ \\
\hline 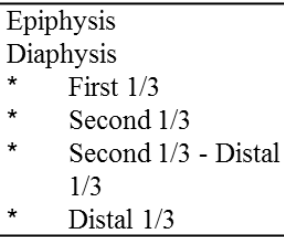 & $\begin{array}{c}27 \\
80 \\
30 \\
34 \\
11 \\
5\end{array}$ & $\begin{array}{c}7 \\
11 \\
5 \\
3 \\
3\end{array}$ & $\begin{array}{c}25.9 \% \\
\\
16.6 \% \\
8.8 \% \\
27.0 \%\end{array}$ & $1-6$ hours \\
\hline 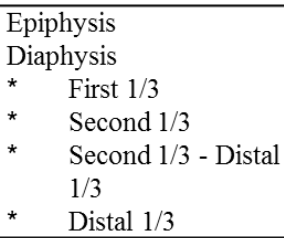 & $\begin{array}{c}14 \\
77 \\
22 \\
32 \\
18 \\
5\end{array}$ & $\begin{array}{l}1 \\
4\end{array}$ & $\begin{array}{l}7.1 \% \\
4.5 \% \\
9.3 \%\end{array}$ & $6-12$ hours \\
\hline 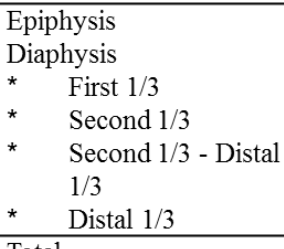 & $\begin{array}{c}7 \\
63 \\
10 \\
35 \\
10 \\
8\end{array}$ & $\begin{array}{l}2 \\
1\end{array}$ & $\begin{array}{l}10.2 \% \\
10.1 \%\end{array}$ & $12-24$ hours \\
\hline
\end{tabular}

\section{Discussions}

The CS incidence in the prospective casuistry was $9.3 \%$. Proximal epiphyseal fracture localizations (tibia and peroneus) have a major risk $(16 \%)$ and can develop CS in the first 6 hours from the accident [6].

The high diaphyseal fractures (first $1 / 3$ ) have a risk of $11.6 \%$, value which decrease in second $1 / 3$ to $9 \%$ and even $6 \%$. For the fractures in the second $1 / 3$, the evolution interval to CS can be 12 hours and even 24-48 hours which impose pressure monitorisation to the whole interval.

The direct traumatic mechanism presents a major risk (72\%), and the gravity of CS is given by the association of crush lesions with pressional ischemia. The ischemic pressional effect is extended on tissular structures which are situated at the border line of viability. This situation characterizes the traumatism with high and medium energy.

The fracture characteristics as the number of fragments is not concluding when are analyzed separately, being no correlation with the risk of CS. A comminuted fracture can slow down the beginning of CS, but cannot stop it.

The integrity of the tegument are very important for the develop of CS in a short period of time. The presence of CS in case of open fractures $(36 \%)$ show their risk, but the period of time needed to develop can be longer as 10 hours to 48 hours, with incomplete and unconvincing clinical manifestations. Politrauma was associated in $43 \%$ of cases, being a risk factor due to hemodynamic implications [7].

The pressional interval of $20-30 \mathrm{mmHg}$ represents an alarm interval due to microcirculatory hemodynamic instability. The fractures situated in that pressional interval can develop in double sense

Table IX - Prospective group 2012-2014

- evaluation of the etiopathogenical factor risks in relation with the pressional intervals - statistical aspects of the casuistry and of the cases that evolved to CS

\begin{tabular}{||l|l|c|c|c|c|c|c|c||}
\hline \hline \multirow{2}{*}{$\begin{array}{l}\text { Pressure } \\
\text { interval }\end{array}$} & & \multicolumn{2}{|c|}{ Mechanism } & \multicolumn{2}{c||}{ Aspects } & \multicolumn{2}{|c||}{ Soft tissue } & \multirow{2}{*}{ Politrauma. } \\
\cline { 2 - 9 } & & Direct & Indirect & Comminuted & Simple & $\begin{array}{c}\text { Closed } \\
\text { fracture }\end{array}$ & Open & \\
\hline $\begin{array}{l}15-20 \\
\mathrm{mmHg}\end{array}$ & group & $46.9 \%$ & $53.1 \%$ & $47.7 \%$ & $52.2 \%$ & $53.9 \%$ & $46 \%$ & \\
\cline { 2 - 9 } & CS & $7.7 \%$ & $3.3 \%$ & $9.4 \%$ & $16.6 \%$ & $6.7 \%$ & $3.8 \%$ & $33.3 \%$ \\
\hline $\begin{array}{l}21-25 \\
\mathrm{mmHg}\end{array}$ & group & $63.1 \%$ & $36.8 \%$ & $38.8 \%$ & $61.1 \%$ & $62.1 \%$ & $37.8 \%$ & $12.6 \%$ \\
\cline { 2 - 9 } & CS & $3 \%$ & $7.8 \%$ & $2.5 \%$ & $6.3 \%$ & $6.25 \%$ & $2.5 \%$ & $60 \%$ \\
\hline $\begin{array}{l}26-30 \\
\mathrm{mmHg}\end{array}$ & group & $71.8 \%$ & $28.1 \%$ & $65.7 \%$ & $34.3 \%$ & $75 \%$ & $25 \%$ & $25 \%$ \\
\cline { 2 - 9 } & CS & $21.7 \%$ & & $9.5 \%$ & $27 \%$ & $12.5 \%$ & $25 \%$ & $60 \%$ \\
\hline $\begin{array}{l}31-40 \\
\mathrm{mmHg}\end{array}$ & group & $35.7 \%$ & $64.2 \%$ & $50 \%$ & $50 \%$ & $85.7 \%$ & $14.2 \%$ & $14.2 \%$ \\
\cline { 2 - 9 } & CS & 1 S.C. & & 1 S.C. & & & 1 S.C. & \\
\hline $\begin{array}{l}41-100 \\
\mathrm{mmHg}\end{array}$ & group & & & & & & & \\
\cline { 2 - 9 } & CS & 5 S.C. & 3 S.C. & 3 S.C. & 5 S.C. & 4 S.C. & 4 S.C. & $50 \%$ \\
\hline \hline
\end{tabular}


(normalization or worsening), in time period of 3-24 hours [8].

We propose a consultative evaluation score of the etiopathogenic risk which can be applied for the pressional interval of $20-30 \mathrm{mmHg}$.

1. Fracture localization

- tibia - 1 point

- peroneus -0

- both -2

2. Localization

- epiphyseal proximal - 3

- epiphyso-diaphyseal - 3

- diaphyseal first $1 / 3-2$

- diaphyseal second $1 / 3-2$

- diaphyseal distal $1 / 3-0$

3. Traumatic mechanism

- direct -3

- not direct - 1

4. Time interval from accident to first manometry

- 1-6 hours -3

- 6-12 hours -2

- 12-24 hours -1

5 . Soft tissue quality

- closed fractures -2

- open fractures type I Gustilo - 2

- open fractures type II and IIIA - 1

6. Politrauma association -1

7. Age

$->50$ years -0

$-<50$ years -1

8. Associated circulatory disease as high blood pressure or peripheric circulatory deficiency (relative value)

- present -1

- absent - 0

The unpredicted character of the evolution of some tibia fractures imposes pressional monitoring of the cases that have a minimum score of 10 points. The secondary decreasing of pressional level in the compartment can exclude the risk of CS.

\section{Conclusions}

The compartmental pressure with ischemic effect on the compartmental anatomical structures is generated by a tissular edema with extended evolution, resulted as a malfunction of the liquid exchange in capillary, a deficit of lymphatic drainage and a pathologic increase of the capillary permeability.

Ischemia will have a progressive evolution and will affect all the structures of the compartment through a vicious circle edema-ischemia-high pressure.

CS represents an unpredicted state of the beginning, of evolution and the lesional determinism.

The principal risk factors selected are: fracture localization, fracture characteristics, type of traumatic mechanism, soft tissue quality, tegument quality, politrauma, age, pressional level.

The analyzed etiopathogenic criterions must be correlated with the dynamic of the pressional levels. The increase of the pressional level over $20 \mathrm{mmHg}$ can be evaluated as the beginning of a microcirculatory hemodynamic imbalance with possible risk of CS. The pressional interval of $20-30 \mathrm{mmHg}$ can be correlated with the etiopathogenic factors using the risk score we described.

The presence of a pressional level between 25$30 \mathrm{mmHg}$ after 3-6 hours from the accident, with a risk score over 8 points represent an indicator of high importance of evolution to CS.

\section{References}

1. Matsen, F. (1975). Compartmental Syndrome an Unifield Concept. Clinical Orthopaedics and Related Research. 13, 8-13

2. Ashton, H. (1975). The Effect of Increased Tissure on Blood. Clinical Orthopaedics and Related Research. 13, 3-7 
3. Godinger, J., Huc, de Bat J.M. \& Lecestre, P. (1979). Syndrome ischemique post-traumatic des loges de la jambe. Rev. de Chirurgie Orthop. 65, 221-229

4. Engelund, D. \& Kjersgaard, A.G. (1991). Acute Compartment Syndrome, Ugeskr. Laeger. 153(16), 1110-1113

5. Whiteside, T.H., Haney, T.H., Kazou, M. \& Harada, H. (1975). Tissue Pressure Measurement as a Determinant for the Need of Fasciotomy, Clinical Orthopaedics and Related Research. $13,13-50$
6. Andrews, J.R., Tedder, J.L. \& Godbout, B.P. (1992). Bicondylar Tibial Plateau Fracture Complicated by Compartment Syndrome. Ortop. Review. 21(3), 317-319

7. Blick, S., Brumback, R., Poka, P., Burgess, A. \& Ebraheim N. (1996). Compartment Syndrome in Open Tibial Fractures. J. Bone and Joint Surgery. 68-A, 9, 1348-1352

8. Janzing, H.M.J. \& Broos, P.L.O. (1999). The Routine Monitoring of the Compartment Pressure in Patients with a Tibial Fracture. A Prospective Clinical Study, SICOT. 569, 18-23 